\title{
Decreased protein catabolism after exercise in subjects with IDDM
}

\author{
J.T.Devlin ${ }^{1}$, A.Scrimgeour ${ }^{2}$, I. Brodsky ${ }^{2}$, S. Fuller ${ }^{2}$ \\ ${ }^{1}$ Division of Endocrinology, Maine Medical Center, Portland, Maine, USA \\ ${ }^{2}$ Metabolic Unit, University of Vermont College of Medicine, Burlington, Vermont, USA
}

\begin{abstract}
Summary We examined whether the increased rates of protein catabolism (proteolysis and leucine oxidation) associated with moderate insulinopenia in subjects with IDDM would be accentuated by prior bicycle exercise $\left(53 \% \mathrm{VO}_{2 \max }\right.$ for $\left.82 \mathrm{~min}\right)$. Insulin infusions maintained plasma glucose concentrations on one study day in "tight" control (TC: $6 \mathrm{mmol} / \mathrm{l}$ ) and on a separate day in "loose" control (LC: $12 \mathrm{mmol} / \mathrm{l})$. Elevations in serum ketone body, plasma NEFA, and whole-blood branched-chain amino acid concentrations on the loose control day during the basal period persisted throughout the post-exercise recovery period. Amino acid kinetics were estimated during a primed, constant infusion of $\mathrm{L}-\left[1-{ }^{13} \mathrm{C}\right]$ leucine from plasma dilution of $\alpha-\left[1-{ }^{13} \mathrm{C}\right] \mathrm{KIC}$ and expired air ${ }^{13} \mathrm{CO}_{2}$ enrichments. Loose control was associated with increased rates of whole-body leucine oxidation (LC $25 \pm 7$ vs TC $21 \pm 8 \mu \mathrm{mol} \cdot \mathrm{kg}^{-1} \cdot \mathrm{h}^{-1}$ ) and protein degradation (LC $127 \pm 12$ vs TC $118 \pm 18 \mu \mathrm{mol} \cdot \mathrm{kg}^{-1} \cdot \mathrm{h}^{-1}$ ) (both $p<0.05)$. During the 2 -h post exercise recovery period,
\end{abstract}

there were significant decreases in rates of leucine oxidation (LC 21 \pm 7 , TC $16 \pm 7$ ) and protein degradation (LC112 \pm 13, TC107 \pm 11 ), compared to the basal period (both $p<0.05$, basal vs recovery). Rates of wholebody protein synthesis were unchanged by prior exercise. In conclusion, moderate insulinopenia is associated with significantly higher rates of protein degradation and leucine oxidation in the basal state. Following exercise, net protein catabolism is diminished due to reduced rates of protein degradation in the presence of maintained rates of protein synthesis. The significantly increased concentrations of fat-derived substrates (ketone bodies, NEFA) may have prevented the predicted increases in protein catabolism which we anticipated would follow acute exercise during periods of relative insulin deficiency. [Diabetologia (1994) 37: 358-364]

Key words Protein metabolism, exercise, leucine, hyperglycaemia, ketones.
Received: 29 July 1993

and in revised form: 4 October 1993

Correspondence and reprint requests to:

Dr. J.T. Devlin

Division of Endocrinology

Maine Medical Center

22 Bramhall St.

Portland, ME 04102

USA

Abbreviations: IDDM, Insulin-dependent diabetes mellitus; KIC, $\alpha$-ketoisocaproic acid; ANOVA, analysis of variance; $\mathrm{VO}_{2 \max }$, maximal aerobic capacity
Physical exercise has long been recognized as an important component of the management strategy in IDDM, constituting one arm of the insulin-diet-exercise triad [1]. Because of the known risks of hypoglycaemia during and after exercise $[2,3]$ many subjects prefer to exercise when plasma glucose concentrations are moderately elevated, and indeed may utilize exercise as a means to lower elevated glucose concentrations. In insulinopenic, ketotic IDDM subjects with plasma glucose concentrations greater than 15$20 \mathrm{mmol} / \mathrm{l}$, exercise may acutely result in a deterioration of metabolic control with increasing glycaemia and ketosis $[4,5]$.

Many of the catabolic effects of insulin deficiency are also produced during exercise, including increases 
Table 1. Subject characteristics

\begin{tabular}{|c|c|c|c|c|c|c|}
\hline Subject & $\begin{array}{l}\text { Duration } \\
\text { (years) }\end{array}$ & $\begin{array}{l}\mathrm{HbA}_{1 C^{b}} \\
(\%)\end{array}$ & $\begin{array}{l}\text { Age } \\
\text { (years) }\end{array}$ & $\mathrm{BMI}^{\mathrm{c}}$ & $\begin{array}{l}\mathrm{VO}_{2 \max } \\
\left(\mathrm{ml} \cdot \mathrm{kg}^{-1} \cdot \mathrm{min}^{-1}\right)\end{array}$ & $\begin{array}{l}\text { Body fat } \\
(\%)\end{array}$ \\
\hline 1 & 7 & 8.6 & 25 & 23.1 & 45.5 & 16.6 \\
\hline 2 & 9 & 9.1 & 42 & 23.0 & 41.9 & 17.4 \\
\hline 4 & 10 & 7.9 & 28 & 22.3 & 56.0 & 9.1 \\
\hline 5 & 6 & 7.9 & 18 & 24.8 & 43.6 & 19.4 \\
\hline 6 & 13 & 7.3 & 23 & 21.8 & 53.2 & 8.5 \\
\hline SEM & 1.1 & 0.3 & 3.3 & 0.4 & 2.4 & 1.9 \\
\hline
\end{tabular}

${ }^{a}$ Years since diagnosis of diabetes mellitus; ${ }^{\mathrm{b}} \mathrm{HbA}_{1 \mathrm{C}}$ normal range $0-6 \%$; ${ }^{\mathrm{c}} \mathrm{BMI}$, body mass index $=$ weight in $\mathrm{kg} /(\text { height in metres })^{2}$;

${ }^{\mathrm{d}}$ Body fat (\%) estimated from body density (see methods)

in glycogenolysis and gluconeogenesis [6,7], lipolysis and ketogenesis [8] and in protein degradation and leucine oxidation $[9,10]$. We hypothesized that IDDM subjects exercising at moderate workloads $(50-60 \%$ of maximal aerobic capacity, $\left.\mathrm{VO}_{2 \max }\right)$ in "loose" glycemic control $(12 \mathrm{mmol} / \mathrm{l})$ produced by moderate insulinopenia would demonstrate accelerated net protein catabolism (increased protein degradation and leucine oxidation, decreased protein synthesis) during the postexercise recovery period, compared to subjects in "tight" glycemic control $(6 \mathrm{mmol} / \mathrm{l})$. This degree of hyperglycaemia $(12 \mathrm{mmol} / \mathrm{l})$ was chosen to represent a level at which many diabetic subjects may be currently engaging in exercise programs. If loosely-controlled IDDM subjects fail to demonstrate the post-exercise increases in rates of whole-protein synthesis recently reported in non-diabetic control subjects [11], then the exercise prescription may need to be modified to allow these individuals to optimize the protein anabolic responses to physical training programmes.

\section{Subjects, materials and methods}

Six male volunteers with IDDM were recruited. Subject characteristics are given in Table 1 . All subjects had an undetectable Cpeptide concentration ( $<33 \mathrm{pmol} / 1) 90 \mathrm{~min}$ after a standardized liquid meal (Sustacal: 240 kcals, $14.5 \mathrm{~g}$ protein, $5.5 \mathrm{~g}$ fat, $33 \mathrm{~g}$ carbohydrate) [12]. Except for IDDM all subjects were free from significant medical illness as determined by complete medical history, physical examination and screening laboratory chemistries. Specifically, all subjects had either no or minimal background retinopathy, normal blood pressure and kidney function tests, no proteinuria (dipstick test), and intact peripheral nerve function. The design, purpose, and possible risks were carefully explained to each subject before obtaining written consent. The experimental protocol was approved by the University of Vermont Committee on Human Research.

The study was carried out at the University of Vermont Clinical Research Center. Subjects were interviewed by the center's dietician to assure they were ingesting a weight-maintaining diet containing at least $1 \mathrm{~g}$ protein $\cdot \mathrm{kg}$ body weight ${ }^{-1} \cdot \mathrm{day}^{-1}$, with a macronutrient composition conforming with published recommendations of the American Diabetes Association. Subjects were instructed to avoid strenuous physical activity for 5 days prior to each admission to the center. At least 7 days prior to their first admission, each subject underwent a $\mathrm{VO}_{2 \max }$ test using a continuous exercise protocol on a Monarch bicycle [13]. Body composition was estimated from body density using the underwater weighing technique, with lung volumes determined by helium dilution [14].

Subjects were admitted to the center $48 \mathrm{~h}$ prior to the exercise study day on two occasions at least 7 days apart, and with the order randomized between the "tight" (TC) and "loose" (LC) control admissions. On each admission, all intermediate- and long-acting insulin preparations were discontinued, and frequent injections of crystalline (regular) human insulin were given three times per day ante-cibum and before a bedtime snack, with an additional injection as needed at 03.00 hours based on fingerstick glucose determinations, to maintain capillary blood glucose concentrations between 6 and $8 \mathrm{mmol} / \mathrm{l}$. Subjects were fed a weight-maintaining American Diabetes Association diet with protein constituting $20 \%$ of total calories.

Experimental design: On the evening prior to the exercise study day, a continuous intravenous infusion of regular insulin was administered at a rate required to maintain the capillary blood glucose, determined at 30-min intervals throughout the night using an indwelling catheter and without waking the subject, at the target levels: $6 \mathrm{mmol} / \mathrm{l}$ on the "tight" control admission and $12 \mathrm{mmol} / \mathrm{l}$ on the "loose" control admission.

On the morning of the study day in the post-absorptive state, subjects were placed under the ventilated hood at 06.30 hours for measurement of resting metabolic rate using continuous indirect calorimetry [15]. After a 30-40 min steady-state period subjects were removed from the hood. Expired air samples were collected using a breathalyser balloon with a dead space air trap (Protection Devices, San Bernardino, Calif., USA), and an aliquot was injected into a $15-\mathrm{ml}$ Vacutainer tube for later analysis of ${ }^{13} \mathrm{CO}_{2}$ enrichment. Four baseline expired air samples were taken at 5 -min intervals. At approximately 07.00 hours, a 19-gauge indwelling catheter was inserted in a left antecubital vein (infusion catheter). A 19-gauge indwelling needle was inserted in a left hand vein, and the hand was warmed in a heated box $\left(65-70^{\circ} \mathrm{C}\right)$ for obtaining "arterialized" blood specimens. Two arterialized blood samples $5 \mathrm{~min}$ apart were taken for determining background amino acid enrichments, and a sample for background ${ }^{3} \mathbf{H}$-specific activity. After baseline sampling the following primed continuous infusions were given at time 0 : $\mathrm{NaH}^{13} \mathrm{CO}_{3}$, $0.08 \mu \mathrm{mol} / \mathrm{kg}$ bolus $\left(99 \%{ }^{13} \mathrm{C}\right)$; and $\mathrm{L}-\left[1-{ }^{13} \mathrm{C}\right]$ leucine, $2 \mu \mathrm{mol} / \mathrm{kg}$ bolus followed $2.4 \mu \mathrm{mol} \cdot \mathrm{kg}^{-1} \cdot \mathrm{h}^{-1}$ infusion $\left(99 \%{ }^{13} \mathrm{C}\right.$; MSD Isotopes, Montreal, Quebec, Canada); D-[3- $\left.{ }^{3} \mathrm{H}\right]$ glucose, $25 \mu \mathrm{Ci}$ bolus and $0.25 \mu \mathrm{Ci} / \mathrm{min}$ infusion (NEN, Boston, Mass., USA, determined to contain less than $0.8 \%{ }^{3} \mathrm{H}$-contaminant [16]. Subjects were again placed in the ventilated hood for continuous indirect calorimetry readings. The intravenous insulin infusion was 
continued at a rate required to maintain whole-blood glucose concentration, determined every $10 \mathrm{~min}$ on a YSI glucose analyser, in the target range of either 6 or $12 \mathrm{mmol} / 1$.

Sampling procedures: Blood samples were taken from the arterialized hand catheter at 15 -min intervals during the 120 - to 180 min basal (pre-exercise) steady-state period. Expired air samples were taken for ${ }^{13} \mathrm{CO}_{2}$ enrichment at 15 -min intervals, and $\mathrm{CO}_{2}$ production rate continuously determined using indirect calorimetry, during the basal steady-state period.

Exercise protocol: Beginning at approximately 10.30 hours, subjects exercised on the Monarch bicycle at a workload calculated to represent $50-60 \%$ of the individual's predetermined $\mathrm{VO}_{2 \max }$. The insulin infusion rate was empirically reduced by $30-50 \%$ of the basal infusion rate in an effort to maintain whole-blood glucose concentrations, determined at 10 -min intervals, in the target range during and after exercise. Blood sampling from the arterialized hand vein catheter and expired air collections were taken at 20-min intervals throughout the period of exercise. Expired air collections during exercise were collected using a mouthpiece connected via a J-valve to a 120 -litre Tissot spirometer (Collins, Boston, Mass., USA). A 15-ml aliquot was taken in a Vacutainer tube for later determination of ${ }^{13} \mathrm{CO}_{2}$ enrichment, and aliquots were analysed for $\mathrm{O}_{2}$ content using a zirconium fuel-cell analyser and for $\mathrm{CO}_{2}$ using an infrared analyser (Applied Electrochemistry, Sunnyvale, Calif., USA). Subjects were encouraged to exercise until they were too fatigued to continue, for a total duration of at least $60 \mathrm{~min}$ up to a maximum of $120 \mathrm{~min}$. During exercise an estimate of perceived exertion, using a modification of the Borg scale [17], ranging from 0 (no effort) to 10 (very strong effort), was made at 15 -min intervals by the subject. Each subject exercised for the identical total duration and at the identical absolute workload on his two separate exercise study days.

During the post-exercise recovery period, subjects remained lying in bed. Blood sampling was taken from the arterialized hand vein, and expired air collections for ${ }^{13} \mathrm{CO}_{2}$ enrichments, were taken at 20 -min intervals. Oxygen consumption and carbon dioxide production rates were continuously determined using indirect calorimetry. The insulin infusion rate was maintained at the reduced (exercise) rate to maintain blood glucose concentrations in the target range.

Whole blood glucose was determined by the glucose-oxidase method using a Yellow Springs Instrument glucose analyser (Yellow Springs, Ohio, USA). Whole blood substrate (lactate, pyruvate, $\beta$-hydroxybutyrate, acetoacetate and glycerol) determinations were made on protein-free filtrates as previously described [18]. Amino acid concentrations were determined on protein-free filtrates of whole blood [19]. Plasma "free" insulin concentrations were measured by radioimmunoassay following polyethyleneglycol precipitation [12]. Plasma C-peptide concentrations were determined by radioimmunoassay using a tyrosylated monkey C-peptide tracer, monkey C-peptide standard and guinea pig antibody GP 644 [12]. Plasma non-esterified fatty acid (NEFA) concentrations were determined using a microfluorometric method [20]. Samples for determining KIC concentrations and enrichments of $\alpha-\left[1-{ }^{13} \mathrm{C}\right] \mathrm{KIC}$ and $\mathrm{L}-\left[1-{ }^{13} \mathrm{C}\right]$ leucine were centrifuged at $4^{\circ} \mathrm{C}$, and plasma samples were stored at $-80^{\circ} \mathrm{C}$ until analysis could be performed. $\mathrm{D}-\left[3{ }^{3} \mathrm{H}\right]$ Glucose samples were processed as previously described [21]. The specific activities were used to estimate the rates of appearance of glucose during the basal, exercise and post-exercise recovery periods, using the non-steady-state equations of Steele [22].

Calculations: Plasma leucine kinetics were determined using steady-state isotope dilution techniques as described by Matthews et al. $[23,24]$. Under steady-state conditions, the rate of

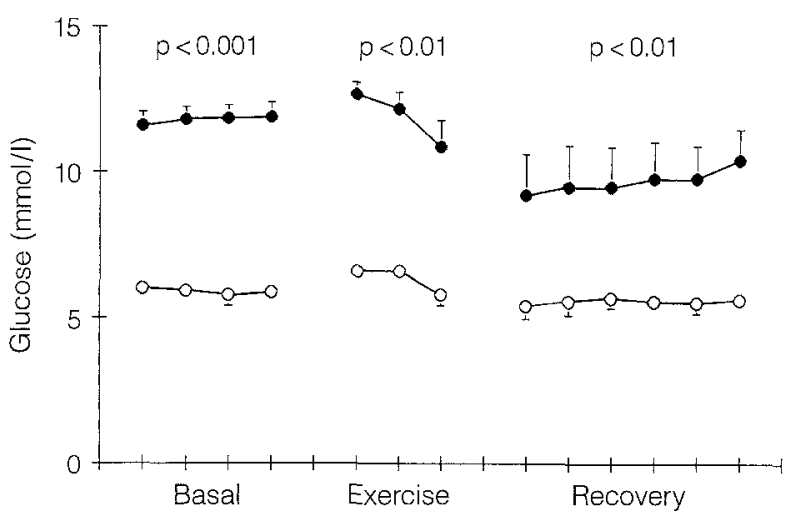

Fig.1. Whole-blood glucose concentrations in arterialized hand vein samples, in the basal (left), exercise (middle) and post-exercise (recovery, right) periods, comparing studies in tight control $(O)$ to loose control ( ) $p$ values indicate significant differences between tight and loose control study days (ANOVA)

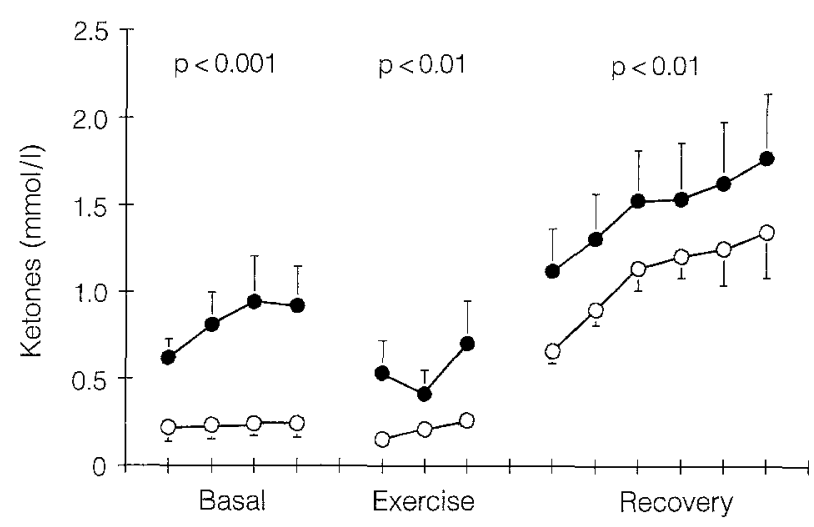

Fig. 2. Whole-blood ketone body ( $\beta$-hydroxybutyrate and acetoacetate) concentrations in the basal (left), exercise (middle) and post-exercise (recovery right) periods, comparing studies in tight control $(O)$ to loose control (O). $p$ values indicate significant differences between tight and loose control study days (ANOVA)

appearance $(\mathrm{Ra})$ is equal to the rate of disappearance ( $\mathrm{Rd})$ of leucine. For the determination of leucine oxidation $\left(\mathrm{Rd}_{\mathrm{ox}}\right)$ rates, steady-state plasma enrichments of $\alpha-\left[1-{ }^{13} \mathrm{C}\right] \mathrm{KIC}$ were used to reflect the immediate precursor for the oxidative decarboxylation of leucine [25]. Estimates of leucine $\mathrm{Ra}$ (an estimate of whole-body protein degradation) and the difference between leucine $\mathrm{Rd}$ and $\mathrm{Rd}_{\mathrm{ox}}\left(\mathrm{Rd}_{\text {non-ox }}\right.$, an estimate of whole-body protein synthesis rates) were made with plasma enrichments of $\alpha$-[1$\left.{ }^{13} \mathrm{C}\right] \mathrm{KIC}$, taken to reflect the intracellular enrichment of leucine. We have examined the rate of recovery of ${ }^{13} \mathrm{CO}_{2}$ in expired breath samples during a primed, constant infusion of $\mathrm{NaH}^{13} \mathrm{CO}_{3}$ [11] at rest, and found it to be the same in four subjects under both loose $(78 \pm 0.6 \%)$ and tight $(75 \pm 6.7 \%)$ glycaemic control conditions as seen in our non-diabetic control subjects (75 $\pm 0.6 \%$; also [11]). We have previously shown that the rate of ${ }^{13} \mathrm{CO}_{2}$ recovery during $\mathrm{NaH}^{13} \mathrm{CO}_{2}$ infusion during this $(2-3 \mathrm{~h}$ ) post-exercise recovery period was identical to that seen in the resting state [11]. Therefore, we used our previous correction factor $(0.78)$ for bicarbonate fixation rate.

Analytical methods: Plasma enrichments of KIC were determined from the trimethylsilyl-quinoxalinol derivatives of KIC, 
Table 2. Arterialized whole-blood concentrations

\begin{tabular}{lll}
\hline & $\begin{array}{l}\text { Concentration } \\
(\mathrm{mmol} / \mathrm{l})\end{array}$ \\
\cline { 2 - 3 } & Basal & Recovery \\
\hline $\begin{array}{l}\text { Glucose } \\
\text { TC }\end{array}$ & $\begin{array}{l}5.90 \pm 0.63 \\
\text { LC }\end{array}$ & $5.58 \pm 0.83$ \\
Lactate & $11.81 \pm 1.1^{\mathrm{b}}$ & $9.60 \pm 3.0^{\mathrm{a}, \mathrm{b}}$ \\
TC & $0.50 \pm 0.07$ & $0.60 \pm 0.09^{\mathrm{a}}$ \\
LC & $0.60 \pm 0.09^{\mathrm{b}}$ & $0.90 \pm 0.29^{\mathrm{a}, \mathrm{b}}$ \\
Pyruvate & & \\
TC & $0.06 \pm 0.01$ & $0.09 \pm 0.04^{\mathrm{a}}$ \\
LC & $0.06 \pm 0.01$ & $0.09 \pm 0.03^{\mathrm{a}}$ \\
\hline
\end{tabular}

TC, Tight control (6 mmol/l); LC, loose control (12 mmol/l); ${ }^{a} p<0.01$, basal vs recovery;

${ }^{\mathrm{b}} p<0.01$, TC vs LC (ANOVA)

Table 3. Arterialized whole-blood amino acid concentrations

\begin{tabular}{|c|c|c|}
\hline & \multicolumn{2}{|c|}{$\begin{array}{l}\text { Concentration } \\
(\mu \mathrm{mol} / \mathrm{l})\end{array}$} \\
\hline & Basal & Recovery \\
\hline $\begin{array}{c}\text { Alanin } \\
\text { TC } \\
\text { LC }\end{array}$ & $\begin{array}{l}243 \pm 16 \\
257 \pm 11\end{array}$ & $\begin{array}{l}263 \pm 20 \\
296 \pm 18^{\mathrm{a} b}\end{array}$ \\
\hline $\begin{array}{c}\text { Glutan } \\
\text { TC } \\
\text { LC }\end{array}$ & $\begin{array}{l}561 \pm 22 \\
569 \pm 33\end{array}$ & $\begin{array}{l}561 \pm 33 \\
558 \pm 38\end{array}$ \\
\hline $\begin{array}{c}\text { Isoleud } \\
\text { TC } \\
\text { LC }\end{array}$ & $\begin{array}{l}49 \pm 2 \\
63 \pm 3^{b}\end{array}$ & $\begin{array}{l}53 \pm 4^{a} \\
63 \pm 7^{b}\end{array}$ \\
\hline $\begin{array}{c}\text { Leucin } \\
\text { TC } \\
\text { LC }\end{array}$ & $\begin{array}{l}120 \pm 5 \\
154 \pm 4^{b}\end{array}$ & $\begin{array}{l}127 \pm 9 \\
160 \pm 16^{b}\end{array}$ \\
\hline $\begin{array}{c}\text { Lysine } \\
\text { TC } \\
\text { LC }\end{array}$ & $\begin{array}{l}192 \pm 14 \\
197 \pm 16\end{array}$ & $\begin{array}{l}164 \pm 10^{\mathrm{a}} \\
187 \pm 20^{\mathrm{b}}\end{array}$ \\
\hline $\begin{array}{c}\text { Valine } \\
\text { TC } \\
\text { LC }\end{array}$ & $\begin{array}{l}166 \pm 5 \\
200 \pm 4^{b}\end{array}$ & $\begin{array}{l}162 \pm 8 \\
190 \pm 11^{\mathrm{b}}\end{array}$ \\
\hline
\end{tabular}

Data are expressed as mean $\pm \mathrm{SEM}$; TC, tight control (6 mmol/l); LC, loose control (12 mmol/l);

${ }^{a} p<0.05$, basal vs recovery;

${ }^{\mathrm{b}} p<0.05$, TC vs LC (ANOVA)

using selected ion monitoring on a Hewlett-Packard 5988A GCMS. Expired air samples were collected in 15-ml Vacutainer containers and later analysed for ${ }^{13} \mathrm{CO}_{2}$ enrichment using a VG Isogas Series II isotope ratio mass spectrometer.

\section{Statistical analysis}

All data are expressed as mean \pm SEM. Comparisons were made between the tight and loose control days, and between different time periods (basal, exercise, recovery) using ANOVA. When ANOVA indicated significant differences between the two study days, post-hoc Student's $t$-test was used to indicate individual time points for which a difference was demonstrable.

\section{Results}

Subject characteristics are given in Table 1 . There was a negative correlation between the subjects' level of physical fitness $\left(\mathrm{VO}_{2 \max }\right)$ and their percent body fat $(r=-0.83, p<0.05)$.

Exercise period: Each subject exercised at the same absolute workload and for the same total duration $(81.7 \pm 8.3 \mathrm{~min}$; range $60-120 \mathrm{~min})$ on the two study days. The oxygen consumption during the period of exercise was similar on the two days (TC: $24.9 \pm 2.0$; LC: $25.5 \pm 1.7 \mathrm{ml} \cdot \mathrm{kg}^{-1} \cdot \mathrm{min}^{-1}$ ), which represented approximately $53 \%$ of $\mathrm{VO}_{2 \max }$. Perceived exertion during exercise (modified Borg scale) was identical on the two days (TC: $4.0 \pm 0.8 ; \mathrm{LC}: 4.0 \pm 0.5$ ).

Whole blood substrate concentrations are shown in Figures 1 and 2, and Table 2. Target blood glucose concentrations were maintained (TC: 5.9 \pm 0.3 ; $\mathrm{LC}: 11.8 \pm 0.5 \mathrm{mmol} / \mathrm{l})$ in the basal period with continuous insulin infusions of $0.60 \pm 0.23 \mathrm{IU} / \mathrm{h}$ (TC) and $0.21 \pm 0.11 \mathrm{IU} / \mathrm{h}(\mathrm{LC})$, respectively. These insulin infusions resulted in basal serum "free" insulin concentrations of $126 \pm 23$ and $63 \pm 23 \mathrm{pmol} / \mathrm{l}$, respectively $(p<0.001)$. Blood glucose concentrations decreased significantly during and after exercise, despite empiric reduction of insulin infusion rates by $30-50 \%$ during these time periods. The decrease in blood glucose concentration during and after exercise was greater on the loose control than on the tight control day $(p<0.01)$. Arterialized whole blood lactate and alanine (Table 3) concentrations were also greater on the loose than the tight control day $(p<0.005)$. On both days, concentrations of each of the three-carbon gluconeogenic precursors (lactate, pyruvate, alanine) were greater during the recovery period than in the basal state $(p<0.01)$.

Branched-chain amino acid (leucine, isoleucine and valine) concentrations were significantly elevated on the loose control days (Table 3). Plasma leucine concentrations did not change significantly during the 120 $240 \mathrm{~min}$ recovery period. Plasma concentrations of KIC were elevated during the loose vs tight control day $(56.8 \pm 4.8$ vs $51.1 \pm 3.1 \mu \mathrm{mol} / \mathrm{l}$, respectively) $(p<0.05)$. Plasma KIC concentrations also did not change during the $120-240 \mathrm{~min}$ recovery period ( $p>0.97$, change in KIC concentration vs time using ANOVA). Serum ketone body concentrations (Fig.2) were increased three- to four-fold in the basal state on the loose vs tight control day $(p<0.001)$. During exercise this difference was maintained $(p<0.01)$, and a significant post-exercise ketosis occurred on both study days (TC vs LC, $p<0.01$ ). Plasma NEFA concentrations were similarly increased in loose vs tight control both during the basal (TC $412 \pm 54$; LC $732 \pm 85 \mu \mathrm{mol} / \mathrm{l}$ ) and during the postexercise periods (TC $955 \pm 155$; LC $1447 \pm 294 \mu \mathrm{mol} / \mathrm{l}$ ) (both $p<0.05$ ), with the post-exercise concentrations being greater than basal $(p<0.01)$. 
Endogenous glucose production rates: Basal endogenous glucose production was lower on the tight than on the loose control day $(2.65 \pm 0.09 \mathrm{vs} 3.77 \pm 0.10 \mathrm{mg} \cdot \mathrm{kg}$ fat free mass ${ }^{-1} \cdot \mathrm{min}^{-1}$, respectively) $(p<0.001)$. By 60 min of exercise, endogenous glucose production had increased on the tight control day (to $4.41 \pm 0.26$ ) $(p<0.001)$, but not on the loose control day (to $3.78 \pm 0.28 \mathrm{mg} \cdot \mathrm{kg}$ fat free mass $\left.{ }^{-1} \cdot \min ^{-1}\right)(p<0.005$, interaction between study day and time period using ANOVA). During the recovery period, endogenous glucose production remained significantly above basal rates on the tight control day $(3.50 \pm 0.44)$ but not the loose control day $\left(3.08 \pm 0.55 \mathrm{mg} \cdot \mathrm{kg}\right.$ fat free mass ${ }^{-1}$. $\left.\min ^{-1}\right)$.

Amino acid kinetics: Plasma enrichments of $\alpha-[1$ $\left.{ }^{13} \mathrm{C}\right] \mathrm{KIC}$ and enrichments of ${ }^{13} \mathrm{CO}_{2}$ in expired air had reached steady-state plateaus within $60 \mathrm{~min}$ of stopping exercise $\left(p>0.998\right.$ and $p>0.96$, changes in ${ }^{13} \mathrm{C}$ KIC and ${ }^{13} \mathrm{CO}_{2}$ enrichments vs time using ANOVA, respectively). Both leucine $\mathrm{Ra}$ and leucine $\mathrm{Rd}_{\mathrm{ox}}$ rates were significantly higher on the loose, compared to the tight control, study days (both $p<0.02$ ) (Table 4 and Fig. 3). There were significant decreases from the basal to the post-exercise recovery period in both leucine $\mathrm{Ra}$ and leucine $\operatorname{Rd}_{\mathrm{ox}}$ (both $p<0.02$ ) (Table 4). Leucine $\mathrm{Rd}_{\text {non-ox }}$, taken to reflect rates of whole-body protein synthesis, were not significantly different between the study days in the basal period, nor were they significantly different during the recovery period, compared to the basal period. Rates of protein turnover could not be estimated during exercise, because steady-state enrichments of $\alpha-\left[1-{ }^{13} \mathrm{C}\right] \mathrm{KIC}$ (plasma) and ${ }^{13} \mathrm{CO}_{2}$ (air) were not achieved.

We may define a "net catabolic index" as the percentage of leucine flux ( $\mathrm{Ra}$ ) that is terminally lost to oxidation, i.e. $\operatorname{Rd}_{\mathrm{OX}} * 100 / \mathrm{Ra}$. This net catabolic index was similar in the basal period on the two study days (TC $21 \%$, LC $23 \%$ ) and showed similar decreases during the post-exercise period (TC 15\%, LC 17\%). These results can be qualitatively compared with our previous data in non-diabetic volunteers (basal 16\%, recovery $10 \%$ ), although neither the subjects nor the exercise protocol were matched between these two studies.

Energy expenditure: in the basal state was similar on the two study days (TC $1.38 \pm 0.05 ;$ LC $1.53 \pm$ $0.11 \mathrm{kcal} / \mathrm{min}$ ), with no significant change during the recovery period (TC $1.51 \pm 0.10$; LC $1.61 \pm$ $0.11 \mathrm{kcal} / \mathrm{min}$ ). Plasma norepinephrine concentrations were similar on the two study days, in both the basal (TC $149 \pm 31$; LC $143 \pm 14 \mathrm{pmol} / \mathrm{l}$ ) and the post-exercise recovery periods (TC $165 \pm 22$; LC $249 \pm$ $77 \mathrm{pmol} / \mathrm{l})(\mathrm{p}=\mathrm{NS})$.

Correlations: Plasma norepinephrine concentrations were significantly correlated with plasma NEFA

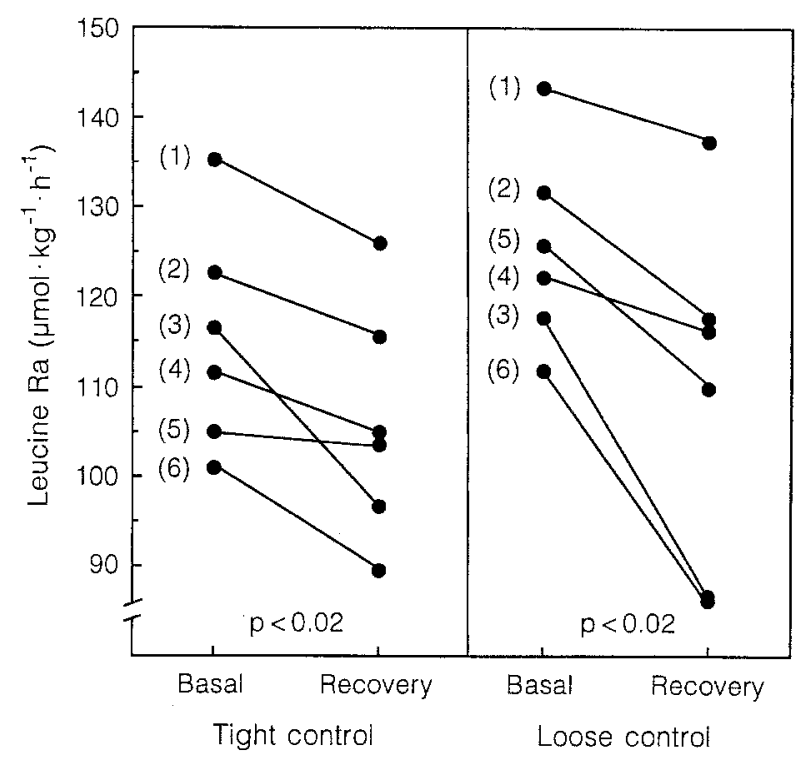

Fig.3. Leucine rates of appearance ( $\mathrm{Ra}$ ) for each subject, in the basal and post-exercise recovery steady-state (180-240 min) periods, on both the tight control (left) and loose control (right) study days. Individual subjects are identified by the numbers in parentheses to the left of the basal data points. $p<0.02$, significant decrease in leucine $\mathrm{Ra}$ between basal and recovery periods, on both tight and loose control study days. Basal leucine Ra was significantly higher on the loose, compared to the tight, control study day $(p<0.02)$

Table 4. Rates of whole-body leucine appearance, oxidation and non-oxidative disposal

\begin{tabular}{llc}
\hline & \multicolumn{2}{l}{$\begin{array}{l}\text { Rates of whole-body protein } \\
\text { turnover }\left(\mu \mathrm{mol} \cdot \mathrm{kg}^{-1} \cdot \mathrm{h}^{-1}\right)\end{array}$} \\
\cline { 2 - 3 } & Basal & Recovery \\
\hline $\begin{array}{l}\text { Leucine appearance }(\mathrm{Ra}) \\
\text { TC }\end{array}$ & $118 \pm 18$ & $107 \pm 11^{\mathrm{a}}$ \\
LC & $127 \pm 12^{\mathrm{b}}$ & $112 \pm 13^{\mathrm{a}, \mathrm{b}}$ \\
Leucine oxidation $\left(\mathrm{Rd}_{\mathrm{ax}}\right)$ & & \\
TC & $21 \pm 8$ & $16 \pm 7^{\mathrm{a}}$ \\
LC & $25 \pm 7^{\mathrm{b}}$ & $21 \pm 7^{\mathrm{a}, \mathrm{b}}$ \\
$\begin{array}{l}\text { Leucine non-oxidative } \\
\text { disposal }\left(\text { Rd } d_{\text {non-ox }}\right)\end{array}$ & & \\
TC & & \\
LC & $93 \pm 17$ & $91 \pm 13$ \\
\hline
\end{tabular}

Data are mean \pm SEM; TC, Tight control $(6 \mathrm{mmol} / 1) ; \mathrm{LC}$, loose control $(12 \mathrm{mmol} / \mathrm{l})$;

${ }^{\text {a }} p<0.02$, basal vs recovery;

${ }^{\mathrm{b}} p<0.02$, TC vs LC (two-way ANOVA)

$(r=0.74)$ and with blood $\beta$-hydroxybutyrate $(r=0.88)$ concentrations $(p<0.01)$, and concentrations of these fat-derived substrates correlated with each other $(r=0.88, p<0.01)$. Leucine $\mathrm{Rd}_{0 \mathrm{x}}$ rates correlated moderately with rates of total energy expenditure $(r=0.49, p<0.05)$. The correlation coefficient between the decrease in leucine $\mathrm{Ra}$ (from the basal to the recovery periods) and the increase in plasma NEFA concentrations was $r=-0.45(p=0.06)$. 


\section{Discussion}

Incorporating regular physical exercise into the daily routine of patients with IDDM requires careful supervision to avoid either hypoglycaemia [2,3] or metabolic decompensation in poorly-controlled subjects $[4,5]$. The usual clinical recommendation is to have patients exercise during periods of moderate hyperglycaemia in order to avoid hypoglycaemia either during or shortly after exercise. Post-exercise ketosis [26] may place the moderately insulinopenic diabetic patient at significant risk during the recovery period.

Insulin plays a pivotal role in the regulation of protein metabolism by promoting protein synthesis in animals [27] and inhibiting protein degradation both in animal and human studies [28]. Insulin deficiency has previously been shown to increase protein degradation and leucine oxidation rates in humans [9]. The present study demonstrates this increased protein catabolism at much lower degrees of hyperglycaemia - i.e. those frequently encountered in clinical practice.

We hypothesized that moderately insulinopenic subjects would fail to demonstrate the normal net protein anabolic response following exercise. Surprisingly, both tightly $(6 \mathrm{mmol} / \mathrm{l})$ and loosely $(12 \mathrm{mmol} / \mathrm{l})$ controlled IDDM subjects showed a decrease in net protein catabolism during the recovery period, compared to the basal state. Our calculated values for the "net catabolic index" (the percent of leucine Ra lost to oxidation) revealed nearly identical decreases in net protein catabolism induced by prior exercise on both loose and tight control study days. It is possible that the significant elevations in plasma NEFA $(2 \times)$ and ketone body $(3-4 \times)$ concentrations were responsible for limiting protein catabolism on the loosely-controlled study days, since NEFA and $\beta$-hydroxybutyrate infusions have been shown to decrease protein degradation [29] and increase protein synthesis rates [30], respectively. In addition, elevations in branched-chain amino acid concentrations on loosely-controlled study days may promote skeletal muscle protein synthesis [31].

These IDDM subjects achieved net protein anabolism by decreasing protein degradation with unchanged protein synthesis rates during the recovery period. Of interest, we have recently shown [11] that non-diabetic volunteers demonstrate increased protein synthesis, and unchanged protein degradation, rates during this same time period after exercise. It is possible that IDDM subjects are able to achieve a net anabolic response to prior exercise similar to non-diabetic subjects, although via different mechanisms. Primary metabolic perturbations produced by altered circulating hormone (insulin, glucagon) concentrations may be offset by secondary alterations in circulating substrate (NEFA, ketone body, branched-chain amino acid) concentrations. Further studies are needed to elucidate the actual mechanisms of these responses in insulin-deficient diabetic subjects.
In summary, IDDM subjects in states of moderate insulinopenia (plasma glucose $12 \mathrm{mmol} / \mathrm{l}$ ) demonstrate increased catabolism in the overnight fasted state, with increased protein degradation and leucine oxidation rates and increased availability of fat-derived substrates (NEFA and ketone bodies). Unexpectedly, rates of leucine oxidation and protein degradation both decreased following a period of moderate-intensity cycle exercise, suggesting that these subjects are able to have normal post-exercise net protein anabolism despite altered hormone concentrations. Further studies are needed to define the role of elevated circulating NEFA and ketone body concentrations as possible mediators of this protein anabolic response during the post-exercise recovery period.

Acknowledgements. We would like to gratefully acknowledge the assistance of the University of Vermont Clinical Research Center nursing and dietary staffs, and C.Armstrong, P.Mead and M.O'Connell for excellent technical assistance. We would also like to acknowledge the invaluable technical assistance of B. O'Rourke and D.Ebenstein in the CRC Biomedical Mass Spectrometry Facility, under the direction of Dr. K. S. Nair. This research was supported by NIH Clinical Investigator Award K08-01554, a Juvenile Diabetes Foundation Research Grant, and NIH Award GCRC RR109.

\section{References}

1. Joslin EP (1924) Diabetic manual for the doctor and patient. 3rd edn. Lea \& Febiger, Philadelphia

2. Klachko DM, Lie TH, Cunningham EJ, Chase GR, Burns TW (1972) Blood glucose levels during walking in normal and diabetic subjects. Diabetes 21:89-100

3. Koivisto V, Tronier B (1983) Postprandial blood glucose response to exercise in type I diabetics: comparison between pump and injection therapy. Diabetes Care 6: 36-40

4. Wahren J, Hagenfeldt L, Felig P (1975) Splanchnic and leg exchange of glucose, amino acids, and free fatty acids during exercise in diabetes mellitus. J Clin Invest 55: 1303-1314

5. Berger M, Berchtold P, Cuppers HJ et al. (1977) Metabolic and hormonal effects of muscular exercise in juvenile type diabetes. Diabetologia 13: 355-365

6. Ahlborg G, Felig P (1982) Lactate and glucose exchange across the forearm, legs and splanchnic bed during and after prolonged leg exercise. J Clin Invest 69:45-54

7. Ahlborg G, Felig P, Hagenfeldt L, Hendler R, Wahren J (1974) Substrate turnover during prolonged exercise in man. J Clin Invest 53: 1080-1090

8. Fery F, Balasse EO (1983) Ketone body turnover during and after exercise in overnight-fasted and starved humans. Am J Physiol 245: E318-E325

9. Nair KS, Garrow JS, Ford C, Mahler RF, Halliday D (1983) Effect of poor diabetic control and obesity on whole body protein turnover in man. Diabetologia 25: 400-403

10. Rennie MJ, Edwards RHT, Krywawych S et al. (1981) Effect of exercise on protein turnover in man. Clin Sci 61: 627-639

11. Devlin JT, Brodsky I, Scrimgeour A, Fuller S, Bier DM (1990) Amino acid metabolism after intense exercise. Am J Physiol 258: E249-E255

12. Kuzuya H, Blix PM, Horwitz DL, Steiner DF, Rubenstein AH (1977) Determination of free and total insulin and Cpeptide in insulin-treated diabetics. Diabetes 26: 22-29 
13. Astrand PO, Rodahl K (1986) Evaluation of physical performance on the basis of tests. In: Textbook of Work Physiology: Physiological Bases of Exercise. McGraw-Hill, New York, pp 354-390

14. Goldman RF, Buskirk ER (1961) A method for underwater weighing and the determination of body density. In: Brozek J, Herschel A (eds) Techniques for measuring body composition. Natl Acad Sci, Washington, DC, pp 78-89

15. Meyer HU, Curchod B, Maeder E, Pahud P, Jequier E, Felber J-P (1980) Modifications of glucose storage and oxidation in nonobese diabetics measured by continuous indirect calorimetry. Diabetes 29: 752-756

16. Butler PC, Kryshak EJ, Schwenk WF, Haymond MW, Rizza RA (1990) Hepatic and extrahepatic responses to insulin in $\mathrm{N}$ and nondiabetic humans: assessment in absence of artifact introduced by triatiated nonglucose contaminants. Diabetes 39: $217-225$

17. Noble BJ, Borg GAV, Jacobs I, Ceci R, Kaiser P (1983) A category-ratio perceived exertion scale: relationship to blood and muscle lactates and heart rate. Med Sci Sports Exerc 15: 523-528

18. Devlin JT, Calles-Escandon J, Horton ES (1986) Effects of preexercise snack feeding on endurance cycle exercise. J Appl Physiol 60: 980-985

19. Hill DW, Walters FH, Wilson TD, Stuart JD (1979) High performance liquid chromatography determination of amino acids in the picomole range. Anal Chem 51:1339-1341

20. Miles J, Glasscock R, Aikens J, Gerich J, Haymond M (1983) A microfluorometric method for the determination of free fatty acids in plasma. J Lipid Res 24: 96-99

21. Devlin JT, Horton ES (1985) Effects of prior high-intensity exercise on glucose metabolism in normal and insulin-resistant men. Diabetes 34: 973-979

22. Steele R (1959) Influences of glucose loading and of injected insulin on hepatic glucose output. Ann NY Acad Sci 82: 420 430
23. Matthews DE, Motil KJ, Rohrbaugh DK, Burke JF, Young VR, Bier DM (1980) Measurement of leucine metabolism in man from a primed, continuous infusion of $L-\left[1-^{13} \mathrm{C}\right] l e u c i n e$. Am J Physiol 238: E473-E479

24. Matthews DE, Schwarz HP, Yang RD, Motil KJ, Young VR, Bier DM (1982) Relationship of plasma leucine and $\alpha$-ketoisocaproate during a $\mathrm{L}-\left[1-{ }^{13} \mathrm{C}\right]$ leucine infusion in man: a method for measuring human intracellular leucine tracer enrichment. Metabolism 31: 1105-1112

25. Schwenk WF, Beaufrere B, Haymond MW (1985) Use of reciprocal pool specific activities to model leucine metabolism in humans. Am J Physiol 249: E646-E650

26. Passmore R, Johnson RE (1958) The modification of postexercise ketosis (the Courtice-Douglas effect) by environment temperature and water balance. Q J Exp Physiol 43: 352-361

27. Jefferson LS, Koehler JO, Morgan HE (1972) Effect of insulin on protein synthesis in skeletal muscle of an isolated perfused preparation of rat hemicorpus. Proc Natl Acad Sci USA 69: $816-820$

28. Fukagawa NK, Minaker KL, Rowe JW et al. (1985) Insulinmediated reduction of whole body protein breakdown: doseresponse effects on leucine metabolism in postabsorptive men. J Clin Invest 76: 2306-2311

29. Tessari P, Nissen SL, Miles JM, Haymond MW (1986) Inverse relationship of leucine flux and oxidation to free fatty acid availability in vivo. $\mathrm{J}$ Clin Invest 77: 575-581

30. Nair KS, Welle SL, Halliday D, Campbell RG (1988) Effect of $\beta$-hydroxybutyrate on whole body leucine kinetics and fractional mixed skeletal muscle protein synthesis in man. J Clin Invest 82: 198-205

31. Lundholm K, Edstrom S, Ekman L, Karlberg I, Walker P, Schersten T (1982) Protein degradation in human skeletal muscle tissue: the effect of insulin, leucine, amino acids, and ions. Clin Sci 60: 319-326 